\title{
Modeling of the Bond Issue Parameters for the Capital Structure Optimization
}

\author{
Yulia V. Semernina*[0000-0003-2098-795], Kristina A. Odinokova ${ }^{\dagger[0000-0002-8191-1337]}$, \\ Ekaterina A. Nesterenko ${ }^{\ddagger[0000-0002-7634-7022]}$, Eugene A. Korobov ${ }^{\S[0000-0001-7198-5941]}$, \\ Alina S. Usmanova $[0000-0002-8488-0425]$ \\ ${ }^{*} \dagger \ddagger$ Saratov Socio-Economic Institute (branch of Plekhanov Russian University of Economics), Saratov, Russian Federation \\ ${ }^{\S}$ Saratov State University, Saratov, Russian Federation \\ $\S$ korobovea@yandex.ru
}

\begin{abstract}
The article proposes a computational model with eightstep algorithm for usage bond issuance as a systematic instrument to finance corporate assets by optimal capital structure. The crucial model points are methodologically accurate calculation of the average credit spread accounting the difference in maturity of marketable and modeled issues and the consideration of market factors. The model allows using debt financing as a financial manager's tool for funding and lowering cost of capital.

Index Terms-bond issue, computing debt instruments parameters, optimal capital structure, cost of capital, financial simulation model
\end{abstract}

\section{INTRODUCTION}

In the context of the population's reallocated incomes reduction and a decrease in the level of business investment activity in the Russian Federation, cost level reduction becomes a prerequisite for the successful functioning of companies operating in various branches and sectors of the national economy, the implementation of which gives the opportunity to gain a long-term strategic advantage in the competition.

An effective option to optimize the capital structure, leading to lower costs, is the use of bond financing on the Russian stock market, which is optimal for companies with a positive experience in public debt placement on the domestic market.

However, in the present moment the overwhelming majority of bond issuers locating bonds on the Russian stock exchange market, do not consider bonded financing as tool systematic used for the optimisation of the capital structure. In domestic practice it, as a rule, is applied as a tool used for medium-term and long-term capital engagement being attractive alternative to traditional bank crediting, and perceived to bonds issuers as relatively "constant component" in the corporate capital structure, change of which takes place at ransom of bonds within tender or at liquidation (total or partial) of bonded issue.

The predominance of such approach on the national market of public promissory notes is caused by the complexity of accurate mathematical simulation of located bonded issue parameters, first of all, their yield to maturity being the key point for the capital structure optimization. The fact is that application of classical simulation methods for solving the considering applied task allows to receive just a prognosis range of the bond yield to maturity, which is characterized by high degree of error because of the limited volume of initial data for performing the required calculations. At the same time actual level of the yield, which was at the moment of bond issuance, can fall beyond prognosis interval.

The aim of the research is to develop a computational model of corporate bond issue parameters for capital structure optimization, which takes into account such factors as bond issuer's credit metrics and bond market conditions.

\section{LITERATURE REVIEW}

Currently, in the specialized scientific literature, issues related to the bond issue parameters' modelling in the context of the capital structure optimization receive little attention from scientists.

In the vast majority of studies, the modelling of bond issues' parameters is considered by researchers as a standalone task, and the obtained simulation results are considered, first of all, from the position when bond financing is used as one of the sources for raising capital by Russian companies (if the company doesn't have such experience of bond issuance) or from a position of direct comparison with marketable debt securities of the same issuer or analog companies (if the company has experience of bond financing).

One of the most fundamental studies outlined the main notions of the capital structure theory and its relation to the cost of capital is [1]. It considers general principals of corporate theory of financing and investing from the cost of capital point of view. It established the capital structure essentials, highlighted the problem of fund raising when the capital can be obtained by many different media, ranging from pure debt instruments, representing money-fixed claimes, to pure equity issues, giving holders only the right to a pro-rate share in the uncertain venture. All these points were extended by researches in papers [2], [3]. The first one focuses on the relationship between optimal capital structure and debt instruments' default risk. It examines the value of debt subject to default risk in a continuous time framework. By considering debt with regular principal repayments, it examines bonds with arbitrary maturity while retaining a time-homogeneous environment. The second paper [3] examines the optimal capital structure of a firm that can choose both the amount and maturity of its debt. In the study [4] the author investigated 
The proposed formula for calculating the average credit spread when modeling the parameters of bond issues while optimizing the capital structure using bond financing is:

$$
\bar{S}=\frac{\sum_{i=1}^{n} S_{i} f_{i}}{\sum_{i=1}^{n} f_{i}},
$$
computes the values of the firm, debt and equity under this assumption.

The works above consider corporate debt instrument financing as a deep theoretical task within such disciplines as corporate finance, accounting and business administration. More applied aspects of the same problem are presented in papers [6]-[8]. So, the study [6] explores bond yield modeling on the example of infrastructure bonds, author of the paper [7] considers modeling of the public bond yields (federal loan bonds) based on inflation, the study [8] in the process of modelling analyzes the relationship of macroeconomic parameters with the public bonds' yield.

It's necessary to stress out the fact that the consideration of corporate debt instruments is usually scoped by the models simulating default risks, investment alternatives, equity formation. The most of researchers don't pay enough attention to the process of bond issue parameter's computing as a financial manager's systematic tool for managing cost of capital and making its optimal structure.

\section{METHODS}

The first stage of the developed algorithm for modeling the bond issue parameters is to determine the restrictive level of the cost of capital $\left(Y_{R L}\right)$.

This stage involves consolidation and grouping (including a multidimensional one) of the company capital sources in terms of their value followed by their subsequent ranking by this criterion. The purpose of ranking is to consistently distribute the sources of capital by their cost taking into account the size of capital, which allows you to determine the most expensive source of raising capital for the company. This approach allows setting accurate initial guidelines for the volume and maturity of the simulated bond issue: in terms of numbers, these indicators will be equal to the volume and maturity of the company's most expensive source of capital. In fact, with this approach to capital structure optimization, the possibility and expediency of 'replacing' the currently used source (sources) of attracted capital with a bond issue are assessed.

The second stage of the proposed algorithm involves the selection of a benchmark bond issuer and a benchmark yield curve.

In the general case, the yield curve of government bonds or the zero-coupon yield curve characterizing the current temporary structure of interest rates can serve as a benchmark bond yield curve.

The third stage of the algorithm under consideration involves the calculation of the average credit spread $(\bar{S})$ between the yield of the issuer's circulating bonds and the benchmark bond yield. where $S_{i}$ is actual credit spread on the issuer's outstanding $i$ bond issue; $f_{i}$ is the weight assigned to the credit spread on the issuer's outstanding $i$ bond issue; $n$ is the number of circulating issuer's bond issues taken into account in the average credit spread calculation.

To determine the weights $\left(f_{i}\right)$, a dynamic scale is proposed which assumes the determination of weighting factors in proportion to the deviation of the circulating bond issues maturity from the maturity of a simulated bond issue, while the maximum value of the weight coefficient is recognized to be 1 .

To calculate the weight coefficients used, the standard interval $(k)$ is given, measured in days, and the middle of the central interval corresponds to the maturity date of the simulated bond issue (for the central interval $f_{i}=1$ ). Further construction of the dynamic scale is carried out by marking standard intervals on both sides of the central interval, with each standard interval corresponding to a decreasing value of the weight coefficient. The logic of the weight coefficient decrease can be different (for example, it can decrease linearly), however, in any case, the decrease should be symmetrical with respect to the central interval, i.e. only the absolute scale of the deviation is recognized as significant, and should be strictly formalized.

The fourth stage of the developed algorithm requires a preliminary estimate of the yield to maturity of a simulated bond issue $\left(Y_{P}\right)$.

This indicator is calculated as follows:

$$
Y_{P}=Y_{E}+\bar{S}
$$

where $Y_{E}$ is yield on benchmark bonds with a comparable maturity.

At the fifth stage of the algorithm under consideration, it is proposed to identify market factors affecting the bond yield to maturity and a quantitative assessment of their significance.

The importance of this stage of modeling the bond issue parameters in optimizing the capital structure using bond financing is due to the fact that a preliminary assessment of the yield to maturity of a simulated bond issue will be correct only in conditions of an 'absolutely neutral' market environment. In practice, the market situation is characterized by a very high volatility level, therefore, under the influence of market factors, the actual level of bond yield to maturity formed at the time of their placement will highly likely be different from the preliminary assessment of yield to maturity that considered only taking the average credit spread.

The sixth stage of the proposed algorithm involves a quantitative assessment of each factor impact on the yield to 
Table I

KAMAZ PTC BOND ISSUES IN CIRCULATION AS OF JULY 1, 2019 [10]

\begin{tabular}{ccccc}
\hline $\begin{array}{c}\text { Name of bond } \\
\text { issue }\end{array}$ & $\begin{array}{c}\text { Registration } \\
\text { number }\end{array}$ & $\begin{array}{c}\text { Bond placement } \\
\text { start date }\end{array}$ & $\begin{array}{c}\text { Bond repayment } \\
\text { date }\end{array}$ & $\begin{array}{c}\text { Initial nominal } \\
\text { value of the issue, } \\
\text { billion rubles }\end{array}$ \\
\hline Kamaz-5-bob & 4B02-05-55010-D & 19.06 .2015 & 12.06 .2020 & 2.0 \\
Kamaz-4-bob & 4B02-04-55010-D & 30.11 .2015 & 23.11 .2020 & 3.0 \\
Kamaz-BO-P01 & 4B02-01-55010-D-001P & 08.02 .2019 & 04.02 .2022 & 7.0 \\
Kamaz-BO-P02 & 4B02-02-55010-D-001P & 29.03 .2019 & 25.03 .2022 & 6.0 \\
Kamaz-BO-P03 & 4B02-03-55010-D-001P & 14.06 .2019 & 10.06 .2022 & 7.0 \\
Kamaz-12-bob & $4-12-55010-D$ & 06.08 .2015 & 18.07 .2030 & 5.0 \\
Kamaz-13-bob & $4-13-55010-D$ & 24.12 .2015 & 05.12 .2030 & 5.0 \\
Kamaz-14-bob & $4-14-55010-D$ & 12.12 .2016 & 24.11 .2031 & 5.0 \\
Kamaz-15-bob & $4-15-55010-D$ & 20.12 .2016 & 02.12 .2031 & 5.0 \\
Kamaz-7-bob & $4-07-55010-D$ & 24.05 .2018 & 05.05 .2033 & 3.0 \\
Kamaz-8-bob & $4-08-55010-D$ & 24.05 .2018 & 05.05 .2033 & 3.0 \\
Kamaz-9-bob & $4-09-55010-D$ & 29.05 .2018 & 10.05 .2033 & 3.0 \\
Kamaz-10-bob & $4-10-55010-D$ & 29.05 .2018 & 10.05 .2033 & 3.0 \\
Kamaz-11-bob & $4-11-55010-D$ & 29.05 .2018 & 10.05 .2033 & 3.0 \\
\hline
\end{tabular}

maturity of the simulated bond issue as well as their combined effect $\left(D_{M}\right)$ using the methods of economic and mathematical modeling, while:

$$
D_{M}=\sum_{j=1}^{k} d_{j},
$$

where $d_{j}$ is the impact of $j$ market factors on the yield to maturity of a simulated bond issue.

At the seventh stage of this algorithm, the yield to maturity of the simulated bond issue is estimated taking into account the influence of market factors.

This assessment is made by the formula:

$$
Y_{B}=Y_{P}+D_{M}
$$

At the eighth stage of the method, the cost of attracting bond financing is calculated $\left(C_{R}\right)$ and compared with the restrictive level of capital, based on which the conclusion is made on the expediency of bond financing for the company capital structure optimization.

The cost calculation of attracting bond financing (in fact, the coupon rate of the simulated bond issue) is based on the standard model of discount cash flows.

\section{RESULTS}

The developed algorithm for modeling the bond issue parameters while optimizing the capital structure using bond financing was tested using the example of KAMAZ PTC, 'the largest producer of heavy trucks in Russia' 'occupying $45 \%$ of the Russian market' [9] as of July 1, 2019.

KAMAZ PTC systematically uses bond financing to raise capital by placing bonds on the Russian stock market, with 14 issuer's bond issues in circulation at the time of the analysis (Table I).

Since the beginning of 2019, KAMAZ PTC has been offering bonds within the framework of the registered exchange-traded bond program (identification number - 455010-D-001P-02E, assigned on February 21, 2017), under which the 'maximum amount of nominal values' of placed exchange-traded bonds is up to 30 billion rubles inclusive 'or the equivalent of this amount in foreign currency', and 'the maximum exchange bond maturity' cannot exceed 5460 days 'from the placement start date of the exchange bonds issue' [11].

This year the issuer has already placed three bond issues under this program (Kamaz-BO-P01, Kamaz-BOP02, Kamaz-BO-P03) with a total initial nominal value of 20.0 billion rubles. While placing the above-mentioned bond issues, KAMAZ PTC raised funds 'for credit debt refinancing, replenishing working capital and financing investment activities, including the financing of technological upgrade projects' [12]. A fixed coupon rate was established for all placed bond issues for the entire bond circulation period: for the Kamaz-BO-P01 issue $-9.00 \%$ per annum, the KamazBO-P02 and Kamaz-BO-P03 issues - 8.75\%; all bond issues placed under this program are depreciation bonds [13].

According to KAMAZ PTC financial reports, based on the results of the first quarter of 2019 prepared according to Russian accounting standards, as of March 31, 2019, the company capital and reserves amounted to 41.730 billion rubles, long-term liabilities - 68.121 billion rubles, short-term liabilities - 65.117 billion rubles [14] (find a more detailed structure of the issuer's borrowed funds in Table II).

At the time of the study, KAMAZ PTC was considering two alternative options for attracting financing in the amount of 3 billion rubles for a period of 1092 days: bank credit and bond financing (the date of raising finance - July 10, 2019; the date of repayment of the loan - July 6, 2022). Bank credit involved raising the required amount of money at $8.80 \%$ per annum, with quarterly payment of accrued interest and repayment of the entire debt body at the end of the loan term; a third party pledge or guarantee is required (these conditions 
THE STRUCTURE OF BORROWED FUNDS OF KAMAZ PTC AS OF MARCH 31, 2019 (ACCORDING TO RAS), BILLION RUBLES [15]

\begin{tabular}{cc}
\hline Indicator & Indicator value \\
\hline Long-term borrowed funds including: & 63.174 \\
loans & 11.247 \\
loans, excluding bonded loans & 7.657 \\
bond loans & 44.270 \\
Short-term borrowed funds including: & 29.769 \\
loans & 14.408 \\
loans, excluding bonded loans & 6.911 \\
bond loans & 8.450 \\
\hline
\end{tabular}

were offered to the issuer by two banks - PTC Sberbank of Russia and PTC VTB Bank).

Thus, the cost of a bank loan $-8.80 \%$ per annum - acted as a restrictive level on the cost of capital $\left(Y_{R L}=8.80 \%\right)$, at the same time, the modeling of the bond issue yield was carried out based on the issuer's needs (initial nominal value 3.0 billion rubles; bond maturity - 1092 days; date of bond placement - July 10, 2019; bond maturity date - July 6, 2022).

The coupon-free yield curve based on the Nelson-Siegel model and the data on government bonds traded on the national stock market and updated daily by the Moscow Exchange, was chosen as the benchmark curve [16].

The average credit spread was calculated on the basis of the coupon-free yield curve as of July 1, 2019 (Table III).

Table III

THE COUPON-FREE YIELD CURVE PARAMETERS AS OF JULY 1, 2019 [17]

\begin{tabular}{cc}
\hline Bond maturity, years & Bond yield, \% per annum \\
\hline 0.25 & 6.99 \\
0.50 & 7.01 \\
0.75 & 7.04 \\
1.00 & 7.06 \\
2.00 & 7.15 \\
3.00 & 7.22 \\
5.00 & 7.31 \\
7.00 & 7.38 \\
10.00 & 7.45 \\
15.00 & 7.54 \\
20.00 & 7.58 \\
30.00 & 7.61 \\
\hline
\end{tabular}

A 5-day interval (the weight of this interval is 1), i.e. the interval from July 4 to July 8, 2022, was chosen as the standard interval value used to select KAMAZ PTC bond issues; their data are taken into account when calculating the average credit spread. In this case, we used a discrete linear rule of specific weight change of the recorded bond issues: with a "shift" by one interval (both up and down), the weight coefficient decreases by 0.01 (or $1 \%$ ).

For example, if the repayment date of an already marketable issuer's bond issue falls within the interval from June 29 to July 3, 2022, such bond issue will be assigned a weight of 0.99 (the same weight will be assigned to the issue that falls within the interval from July 9 to July 13, 2022).
KAMAZ PTC marketable bond issues selected in with their weighting coefficients and the actual spread to the coupon-free yield curve (for each bond issue).

With the given parameters, the average credit spread is determined as follows:

$$
\bar{S}=\frac{1.38 \% \cdot 0.70+1.51 \% \cdot 0.79+1.51 \% \cdot 0.95}{0.70+0.79+0.95}=1.47 \% \text {. }
$$

Accordingly, the preliminary assessment of the KAMAZ PTC simulated bond issue yield to maturity is $8.69 \%$ per annum $\left(Y_{P}=7.22 \%+1.47 \%=8.69 \%\right)$.

At the next stage of modeling the parameters of bond issues when optimizing the capital structure using bond financing, 15 market factors were identified that affect the bond yield to maturity; then using the variance analysis and the statistical hypothesis testing method, their significance was checked and its quantitative assessment was given. As follows from the analysis carried out on the basis of statistical data for the period from January 2018 to June 2019 inclusive, there can be identified three statistically significant market factors:

1) interest rate volatility, estimated as the average daily change in the overnight rate MosPrime Rate (the impact on the yield to maturity of KAMAZ PTC simulated bond issue at the time of analysis is $-0.06 \%$ );

2) national currency volatility, assessed through the dynamics of the ruble to the dual currency basket $(-0.07 \%)$;

3) the volume of new bond issues offered by other issuers of comparable or higher credit quality $(+0.19 \%)$.

The cumulative effect of market factors on the simulated bond issue yield to maturity is $+0.06 \%\left(D_{M}=-0.06 \%-\right.$ $0.07 \%+0.19 \%=0.06 \%$, and its value, considering this, will be $8.75 \%$ per annum $\left(Y_{B}=8.69 \%+0.06 \%=8.75 \%\right)$. Given the simulated bond issue depreciation structure, disclosed by the issuer, a yield to maturity of $8.75 \%$ per annum and taking into account the systematic reinvestment of coupon payments by bondholders corresponds to a coupon rate of $8.50 \%$ per annum. Accordingly, in this case, bond financing is more preferable than bank credit in terms of optimizing the capital structure. $\left(Y_{R L}>C_{R}, 8.80 \%>8.50 \%\right)$.

\section{CONCLUSIONS}

The proposed algorithm for modeling bond issue parameters includes the following steps:

1) the determination of a restrictive level of the cost of raising capital;

2) the selection of a benchmark bond issuer and a benchmark yield curve;

3) the calculation of the credit spread average value between the yield of the issuer's marketable bonds and the yield of the benchmark bonds;

4) obtaining a preliminary estimate of the yield to maturity of a simulated bond issue;

5) the detection of market factors affecting the yield to maturity of bonds and a quantitative assessment of their significance; 
Table IV

KAMAZ PTC MARKETABLE BOND ISSUES CONSIDERED IN THE AVERAGE CREDIT SPREAD CALCULATION AS OF JULY 1, 2019

\begin{tabular}{ccccc}
\hline $\begin{array}{c}\text { Name } \\
\text { of bond } \\
\text { issue }\end{array}$ & $\begin{array}{c}\text { Bond yield } \\
\text { to maturity, } \\
\text { \% per annum }\end{array}$ & $\begin{array}{c}\text { Benchmark yield } \\
\text { to maturity, } \\
\text { \% per annum }\end{array}$ & $\begin{array}{c}\text { Actual } \\
\text { credit spread } \\
\%\end{array}$ & $\begin{array}{c}\text { Weight } \\
\text { assigned } \\
\text { to bond issue }\end{array}$ \\
\hline Kamaz-BO-P01 & 8.57 & 7.19 & 1.38 & 0.70 \\
Kamaz-BO-P02 & 8.71 & 7.20 & 1.51 & 0.79 \\
Kamaz-BO-P03 & 8.73 & 7.22 & 1.51 & 0.95 \\
\hline
\end{tabular}

6) an assessment of the influence of each factor on the yield to maturity of a simulated bond issue and their combined effect;

7) an assessment of the simulated bond issue's yield to maturity with consideration of the market factor influence;

8) the calculation of the cost of debt financing attraction and its comparison with the raising capital restrictive level, which results in the decision about advisability of bond financing for optimizing the corporate capital structure.

The key differences of the proposed algorithm are more accurate and methodologically correct calculation of the average credit spread with consideration of the difference in the maturity of marketable and simulated bond issues, and accounting the market factors' impact, that is not provided for in the most part of traditional approaches to bond issue parameters' modelling.

\section{REFERENCES}

[1] F. Modigliani, M. Miller, "The cost of capital, corporation finance and the theory of investment", Am. Econ. Rev., vol. 48(3), pp. 261-297, 1955.

[2] H. E. Leland, "Bond prices, yield spreads, and optimal capital structure with default risk", Working Paper, No. 240, IBER, University of California, Berkeley, 1994.

[3] H. E. Leland, K. Toft, "Optimal capital structure, endogenous bankruptcy and the term structure of credit spreads", J. Finance, vol. 51(3), pp. 9871019, 1996.
[4] B. Hilberink, L. C. G. Rogers, "Optimal capital structure and endogenous default”, Financ. Stoch., vol. 6(2), pp. 237-263, 2002.

[5] O. Le Courtois, F. Quittard-Pinon, "The optimal capital structure of the firm with stable Levy assets returns", Decisions in Economics and Finance, vol. 31(1), pp. 51-72, 2008/

[6] P. A. Lashevsky, "Modeling of the infrastructure bonds' yield", Theory and practice of social development 21, pp. 120-122, 2014.

[7] M. A. Bundin, "OFZ-IN issuance parameters accounting expected inflation”, Financial analytics: problems and solutions, vol. 9(44), pp. 14-27, 2016.

[8] A. Yu. Mikhailov, "The interrelation of macroeconomic parameters and Russian public bonds' YTM", Finance and credit, vol. 22(48), pp. 1827, 2016.

[9] (2019, Jul.1) KAMAZ PTC. [Online]. Available: https://kamaz.ru/about/

[10] (2019, Jul.1) RusBonds Internet project of Finmarket news agency. [Online]. Available https://www.rusbonds.ru/srchsimple.asp

[11] (2019, Jul.1) KAMAZ PTC. [Online]. Available: https://kamaz.ru/investors-and-shareholders/stocks/bonds/

[12] (2019, Jul.1) AO "Finam". [Online]. Available: https://bonds.finam.ru/issue/details0254B00005/default.asp

[13] (2019, Jul.1) KAMAZ PTC. [Online]. Available: https://kamaz.ru/investors-and-shareholders/stocks/bonds/

[14] (2019, Jul.1) KAMAZ PTC. [Online]. Available: https://kamaz.ru/investors-and-shareholders/informationdisclosure/quarterly-reports/

[15] (2019, Jul.1) KAMAZ PTC. [Online]. Available: https://kamaz.ru/investors-and-shareholders/informationdisclosure/quarterly-reports/

[16] (2019, Jul.1) PTC Moscow Exchange. [Online]. Available: https://www.moex.com/a3642

[17] (2019, Jul.1) The Central Bank of the Russian Federation. Available: https://www.cbr.ru/hdbase/zcycparams/zcyc/ 